\title{
Tobacco industry efforts hindering enforcement of the ban on tobacco sales to minors: actions speak $\vec{\circ}$ louder than words
}

\author{
Joseph R DiFranza, William T Godshall
}

\begin{abstract}
Objective - The tobacco manufacturers state that they want to see laws that prohibit the sale of tobacco to minors enacted and enforced. Our purpose was to compare these public statements with the US tobacco industry's legislative agenda at the federal and state levels.

Design - A review of the industry's comments to the US Department of Health and Human Services (DHHS) regarding proposed federal regulations, and an analysis of pro-tobacco state legislation concerning tobacco sales to minors. Results - The industry is strongly opposed to federal regulations requiring states to effectively enforce their laws prohibiting the sale of tobacco to minors. A food industry newsletter reports that the Tobacco Institute has circulated a model state bill concerning underage tobacco sales. Striking similarities between bills from several states would seem to confirm this report. These bills strip communities of enforcement authority while making effective enforcement by state officials virtually impossible.
\end{abstract}

Conclusion - The evidence strongly suggests an industry strategy to undermine efforts to enforce laws prohibiting the sale of tobacco to minors. As has been the case in the past, the tobacco industry is publicly endorsing a socially responsible goal while apparently taking action behind the scenes to ensure that the goal is not achieved.

(Tobacco Control 1996;5:127-131)

Keywords: Law compliance; tobacco industry; youth minors

University of

Massachusetts Medical

Center, Worcester,

Massachusetts, USA

JR DiFranza

SmokeFree

Pennsylvania,

Pittsburgh,

Pennsylvania, USA

WT Godshal

Correspondence to Dr Joseph R DiFranza, Department of Family and Community Medicine,

University of Massachusetts Medical Center, 55 Lake Avenue North, Worcester MA 01655, USA. form of law enforcement that employs minor $\vec{\rho}$ to make periodic supervised attempts t $\vec{\psi}$ purchase tobacco. Experience reveals complis ance testing to be simple, inexpensive, and very effective in reducing illegal sales.

Compliance testing may also be effective in reducing teenage smoking rates. ${ }^{5-6}$ In Woodridge, Illinois, routine merchant compli응 ance testing was associated with a $69 \%$ reduc- tion (from $16 \%$ to $5 \%$ ) in regular smoking among junior high school students (ages 12-13). ${ }^{5}$ In Leominster, Massachusetts, smok $\overrightarrow{0}$ ing among this age group dropped by $44 \%$ (from $14 \%$ to $8 \%$ ) after compliance testing was instituted. ${ }^{6}$ These studies raise hopes that is compliance testing were to be institutec throughout the country, significant progress inf reducing teenage addiction to nicotine could $\frac{1}{2}$ be achieved.

In 1992, Congress enacted legislation tọ encourage states to adopt restrictions on the sale of tobacco to minors and to enforce thenp by conducting compliance tests. ${ }^{7}$ States are required to enact a law and enforce it "in $\$$ manner that can reasonably be expected to reduce the extent to which tobacco producto are available to individuals under the age of 18 ". States are required to conduct random: inspections and to submit annual reports to the DHHS describing the degree to which tobaccer. is available to minors. Non-compliant stateso risk gradual reductions in federal block gran funds from the Substance Abuse and MentaP Health Services Administration. This law is commonly referred to as the Synae. Amendment, after the late Mike Synar, who, as a member of the US House of Representatives from Oklahoma, sponsored the law.

In August 1993, the DHHS proposed regu $-\frac{\omega}{-}$ lations for implementing this law and completed a period of public comment in October $1993 .{ }^{8}$ The proposed regulations? would have set uniform criteria by which the adequacy of state enforcement efforts could beo judged. ${ }^{8}$ Initially, states would have had to ${ }^{\circ}$ demonstrate through compliance tests that no more than $50 \%$ of their merchants are making illegal sales. Over the next three years, illega sales rates would have had to be reduced to $40 \%, 30 \%$, and $20 \%$ of attempted purchases Illegal sales rates close to zero have already? been achieved in several communities that routinely conduct compliance tests. ${ }^{5-6}$ The final regulations, issued on 19 January 1996, allow states to set their own timetable for achieving a $20 \%$ illegal sales rate. ${ }^{9}$ 
The tobacco industry's public stance is that they are opposed to children smoking and are actively discouraging the sale of tobacco to minors. ${ }^{10-14}$ According to Yancey W Ford Jr, executive vice president of the RJ Reynolds Tobacco Company: "the most important factors influencing youth smoking are peer influence, the example of family members and the accessibility of cigarettes - better voluntary enforcement of minimum-age purchase laws currently on the books can reduce youth smoking by at least half." 15 The Philip Morris Company recently announced its "Action Against Access" programme, the latest in a series of voluntary programmes adopted by the tobacco industry for the stated purpose of reducing teen smoking. ${ }^{10-13} 14$

On the surface it would appear that the tobacco industry supports efforts to curtail illegal tobacco sales to minors. Unfortunately, none of the industry's programmes have proven to be effective. ${ }^{316}$ Industry programmes to encourage retailers to obey the law did not result in a statistically significant reduction in infractions in a well-controlled study involving 480 attempts to purchase tobacco. ${ }^{16}$

Because the onset of tobacco use after adolescence is unusual, a sharp reduction in teenage addiction to nicotine could have serious repercussions for the future profitability of the tobacco industry. ${ }^{17}$ It would therefore not be in the tobacco industry's best economic interests to encourage, implement, or permit the implementation of effective measures to reduce teenage tobacco use.

The Brown and Williamson Tobacco Corporation documents have revealed that in matters of public health, the industry has long followed a strategy of espousing a responsible position publicly, while secretly pursuing a contradictory agenda. ${ }^{18}$ Although tobacco companies have spent a considerable sum of money professing their desire to curtail illegal sales, ${ }^{10-12}{ }^{14}$ bills introduced by tobacco-friendly state legislators suggest another agenda. The purpose of this study was to compare the industry's public relations campaign to the agenda reflected by its comments to government agencies and the bills introduced by pro-tobacco legislators.

\section{Methods}

Copies of more than 300 public comments submitted to DHHS in response to the initially proposed regulations to implement the Synar amendment $^{8}$ were obtained, reviewed, and sorted according to their source by the staff of Stop Teenage Addiction to Tobacco (STAT), a children's health advocacy group, based in Springfield, Massachusetts. Comments were submitted by individuals (26), schools (15), tobacco control and health organisations (63), law enforcement officials (12), state and local government officials (100), and members of the tobacco industry (117). The interests of the tobacco industry were represented by letters from legislators, individuals, law firms with tobacco clients, and trade organisations representing the manufacturers, distributors, vending machine operators, and retailers. In this article, the term "tobacco industry" is used broadly to refer to anyone who receives money from tobacco-related commerce, or from those involved in such commerce. In light of the tobacco industry's stated support of laws prohibiting the sale of tobacco to minors, all tobacco industry comments were analysed for evidence of such support.

Copies of state legislation concerning the distribution of tobacco to minors that had been filed by legislators sympathetic to the tobacco industry were obtained through contacts with health advocates in more than a dozen states (Alabama, California, Georgia, Indiana, Kentucky, Massachusetts, Michigan, North Carolina, Pennsylvania, South Dakota, Tennessee, Utah, Washington). The intent was not to identify all such bills nationwide, but only to obtain a sample sufficient to identify common features and language.

\section{Results}

FEDERAL AGENDA

The tobacco industry's comments reflected overwhelming opposition to the DHHS plan to reduce illegal tobacco sales to minors. The industry clearly supports a minimum age law, but is strongly opposed to a federal requirement that states institute meaningful enforcement against merchants who break the law. The comments of the Tobacco Institute and congressman Thomas Bliley (a member of the House of Representatives from Virginia), who claim to represent the interests of the industry as a whole, were repeatedly mirrored in the comments from other industry sources.

The Tobacco Institute wrote:

"On November 1, 1991, Rep. Henry Waxman introduced H.R. 3698. . . As introduced, H.R. 3698 added a new section 1925 to the Public Health Service Act denying Section 1921 grants to any state without a law prohibiting the sale or distribution of tobacco products to persons under the age of 18 , and requiring a state to promise to enforce its law in a manner that could reasonably be expected to reduce 'significantly' the availability of such products to individuals under the age of 18. H.R. 3698, 102d Cong., 1st Sess., p.36 (1991).

While not objecting to a national minimum sales age, the tobacco industry strongly opposed Rep. Waxman's proposed language on the grounds that it was 'so broad that the Secretary [of HHS] could set up any kind of guidelines he chose for enforcement and insist on compliance under threat of loss of funds.' "19

The industry's opposition to a requirement that states enforce their laws is reflected in the actions of congressman Thomas Bliley on the House Subcommittee on Health and the Environment. ${ }^{19}$ Bliley represented a district in which Philip Morris was the largest employer, and he received $\$ 111476$ in tobacco industry contributions from 1985 to $1994 .^{20}$ In its letter to DHHS, the Tobacco Institute wrote, "During the consideration of H.R. 3698, the Subcommittee on Health and the Environment adopted an amendment offered by Rep. Thomas Bliley that retained the requirement of an 18-year-old minimum-age law but contained no language with respect to enforcement."19 
Congress ultimately adopted language that requires states to enforce their laws "in a manner that can reasonably be expected to reduce the extent to which tobacco products are available to individuals under the age of $18 . "$ "7

The Tobacco Institute and congressman Bliley argued to the DHHS that, because the word "significantly" does not appear in the final language, the DHHS cannot issue regulations that would require states to make significant progress in reducing illegal sales. ${ }^{1921}$

The depth of the industry's concern about the prospect that states might be required to demonstrate significant progress in reducing illegal tobacco sales to minors is suggested by a comment from Bliley to DHHS: "I am disappointed that the Department has chosen this course and I strongly urge you to consider the ramifications that a challenge on Constitutional grounds would have on the effort to reduce tobacco use by individuals under the age of 18." 21

Bliley and the Tobacco Institute make it clear that they are not only opposed to requiring states to reduce illegal sales significantly, they are opposed to setting enforcement performance standards of any kind. ${ }^{1921}$ Indeed, although the statute requires states to conduct inspections and to report to the DHHS the extent to which progress has been made in reducing illegal sales, ${ }^{7}$ the Tobacco Institute wants to eliminate the requirement that states report the actual compliance rates measured by their inspections. "For the reasons stated above, HHS should eliminate [section] 96.130(c)(2) (mandating additional laws) and [section] 96.130(f)(1) (setting a performance standard), and it should modify [section] 96.130 (c)(1) to eliminate the compliancemeasurement function of the mandatory inspection programs."19

\section{STATE AGENDA}

The analysis of bills introduced by pro-tobacco legislators in 12 states revealed a remarkable uniformity in content down to the level of the wording of sentences. The Tobacco Institute has told us that it has no model bill (oral communication, 26 September 1994). However, a newsletter from the Food Marketing Institute dated 31 January 1994, suggests that this statement is not correct. "With the 1994 legislative session underway at the state level, the Tobacco Institute (TI) has initiated a major push to seek enactment of their own model bill on cigarette sales even though the HHS regulations have not been finalized."22 The next sentence identifies the Tobacco Institute's 20 "priority target states". ${ }^{22}$

The analysis of the bills reviewed for this study identified the following five common themes.

Use state preemption to deny local governments the authority to regulate the promotion or distribution of tobacco within their borders

Local governments have been the source of much innovation and experimentation in the area of youth access. Pre-emption can strip local government and law enforcement officials of all authority to enact or enforce restrictions on the sale of tobacco to minors, renderingo them powerless to halt illegal sales in their own communities.

Pre-emptive minimum age laws have been $\overrightarrow{5}$ enacted in California, Florida, Iowa, Kentucky Louisiana, Michigan, Mississippi, Montana Nevada, New Mexico, New York, North Caro=o lina, Oklahoma, South Dakota, Tennessee 은 Washington, Wisconsin, and Wyoming. ${ }^{23}$ Simi $-\frac{\overline{-n}}{5}$ lar measures have been introduced in manyळ other states. $^{23}$

\section{Hamper enforcement efforts}

The tobacco industry sometimes argues that new laws are not needed, only better enforcement of existing laws. For exampleji Thomas Lauria of the Tobacco Institute told the Associated Press that "we're trying to help toughen up" enforcement. ${ }^{24}$ Yet the bills introduced by pro-tobacco legislators commonly $\vec{c}_{c}$ strip law enforcement officials of their authority to enforce the law. Authority to ${ }^{\Phi}$ enforce the law is typically restricted to a singlece agency or individual lacking the resources oro expertise necessary to do the job. For example, in Kentucky and Tennessee, the Department of Agriculture is in charge of enforcing the minimum age law. In other states, it is the Sec retary of Revenue or the Attorney General $\stackrel{\perp}{\perp}$ During the first two years that the Department of Agriculture was responsible for enforcement in Kentucky, not a single merchant was? convicted despite documentation that children? aged 12-17 years were able to buy tobacco ato nearly two-thirds of 286 stores tested. ${ }^{25}$

A number of provisions have beenô introduced which may hamper enforcement? efforts. A bill in Utah originally included more? than 20 limitations on how compliance testso could be conducted. ${ }^{26}$ Youths could not be vis-음 ibly pregnant, wear jewelry or makeup, have a. moustache or receding hairline, engage in con- $\frac{0}{3}$ versation, be a known customer, or attempt to buy if three other people were waiting in line. Only police could oversee compliance tests $D$ but only once a year, and must both see and hear the attempted purchase and immediatelyc inform the cashier and manager and introducen the underage inspector.

Place loopholes in the law to make it next to impossible for law enforcement officials to successfully prosecute merchants who are caught selling tobacco to minors

The most common loophole is to provide that it is illegal to "knowingly" or "intentionally" $\propto$ sell tobacco to a minor. To understand how this might hamper prosecutions, one can imagine how difficult it would be to enforce speedo limit laws if prosecutors had to prove that driver "knowingly" or "intentionally" exceeded? the speed limit. Charges against merchants in Georgia and North Carolina have been dismissed by courts on the basis that it could not be proven what the merchant knew. ${ }^{27}$ This approach has proven effective in making the 
law unenforceable and pro-tobacco forces have successfully lobbied for enactment of similar language in Kentucky and South Dakota. ${ }^{28-29}$

Outlaw the use of compliance checks for public health research, citizen activism, investigative reporting, and local law enforcement

Much of the focus on tobacco sales to minors is the result of publicity resulting from compliance checks conducted by hundreds of local activists throughout the country. ${ }^{20} \mathrm{Com}-$ pliance checking by community activists highlights the failure of merchants to obey the law and the failure of law enforcement officials to adequately deal with the problem. Compliance testing has proven to be effective in driving public opinion and spurring change. It is also used by hundreds of local police and health departments to enforce tobacco sales laws.

Bills passed in Georgia, Kentucky, Mississippi, South Dakota, and Tennessee make it illegal for anyone other than a single designated state agency to conduct compliance

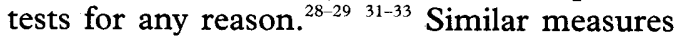
have been introduced in Alabama, California, Indiana, Kentucky, Massachusetts, Oklahoma, and Pennsylvania. The appendix presents excerpts from several of these bills to highlight the similarities in wording that suggest a common source.

The potential effect of these provisions is to hinder enforcement, to limit public knowledge of the fact that illegal sales are occurring, and to hamper further research into the effects of enforcement.

\section{Punish the child, not the merchant}

Bills introduced by pro-tobacco legislators nearly always outlaw the purchase of tobacco by minors. Many bills also include provisions that prevent store owners from being held legally accountable for illegal sales made by their employees. Both tactics serve to shield manufacturers and retailers from responsibility for illegal sales. Making it illegal for minors to purchase tobacco represents an obstacle to employing minors to participate in compliance testing (unless a specific exception is made for compliance tests).

\section{Discussion}

The documents reviewed here make it clear that although the tobacco industry supports a prohibition on the sale of tobacco to minors under the age of 18 , it is opposed to requirements that would result in states effectively enforcing the law.

At the state level, industry-supported measures restricting who can conduct compliance tests can prevent state or local police and health departments from effectively enforcing the law. Even retailers are prevented from testing to determine if their employees are making illegal sales. These measures hamper research and make it difficult for concerned citizens and reporters to shed light on the problem. If the tobacco industry also succeeds in eliminating "the compliance-measurement function of the mandatory inspection programs", ${ }^{19}$ citizens would have to risk arrest to document the extent of illegal sales occurring in their state.

Bills introduced by pro-tobacco legislators severely limit the ability of local and state police to enforce the law by placing a variety of gratuitous restrictions on how, and by who, the law can be enforced, and by providing loopholes that make the successful prosecution of violators virtually impossible. Conspicuously absent from these bills are any measures that would facilitate enforcement, such as providing police or health officials with enforcement authority; providing for both local and state level enforcement; providing a mechanism to fund enforcement; requiring merchants to obtain proper proof of age; employing civil rather than criminal prosecution; and imposing substantial fines and/or provisions for the suspension or revocation of a tobacco retail licence for repeated violations.

The pro-tobacco bills are presented as wellintentioned measures to reduce illegal tobacco sales and thereby help states come into compliance with federal requirements. ${ }^{346}$ In reality, these bills are Trojan horses that will make compliance all but impossible to achieve.

In conjunction with this apparent effort to undermine enforcement of these laws, there is a push to outlaw the purchase or possession of tobacco by minors. Although some health advocates support this policy, ${ }^{36}{ }^{37}$ the tobacco industry may have different motives. Outlawing the possession of tobacco promotes an enforcement approach of arresting children instead of the adults who profit from these illegal sales. In a study of alcohol enforcement, it was found that underage drinkers were arrested for possession of alcohol 47 times more often than merchants were arrested for making underage sales. ${ }^{38}$ The strategy of hampering the prosecution of merchants, while facilitating the prosecution of minors, suggests that the tobacco industry would like to see minors punished in preference to the retailers who supply them with an estimated $\$ 1.25$ billion of tobacco each year. ${ }^{17}$

\section{Conclusion}

Although the tobacco industry claims that it is working to halt the illegal sale of tobacco to minors, an examination of its comments to DHHS and the legislation it supports suggests that it is, in fact, doing a great deal to sabotage efforts to institute meaningful enforcement of laws prohibiting the sale of tobacco to minors. The enactment of so many weak, pre-emptive laws represents a severe blow to public health efforts to reduce the illegal sale of tobacco to children.

The authors wish to acknowledge the contribution of Denise Otkins of Stop Teenage Addiction to Tobacco in conducting the initial review of the public comments to the Department of Health and Human Services.

1 US Department of Health and Human Services, Food and Drug Administration. Regulations restricting the sale and distribution of cigarettes and smokeless tobacco products to protect children and adolescents. Fed Reg 1995 60:41314-787

2 Radecki TE, Zdunich CD. Tobacco sales to minors in 97 US and Canadian communities. Tobacco Control 1993; 2:300-5. 
3 DiFranza JR, Brown LJ. The Tobacco Institute's "It's the Law" campaign: has it halted illegal sales of tobacco to children? Am $¥$ Public Health 1992;82:1271-3.

4 Altman DG, Rasenick-Douss L, Foster V, Tye JB. Sustained effects of an educational program to reduce sales of cigarettes to minors. Am ₹ Public Health 1991;81:891-3.

5 Jason LA, Ji PY, Anes MD, Birkhead SH. Active enforcement of cigarette control laws in the prevention of cigarette sales to minors. $\mathcal{F A M A} 1991 ; 266: 3159-61$.

6 DiFranza JR, Carlson RR, Caisse RE. Reducing youth access to tobacco. Tobacco Control 1992;1:58.

7 Public Health Service Act 42 USC 300x-26 section 1926

8 US Department of Health and Human Services, Substance Abuse and Mental Health Services Administration. Substance abuse prevention and treatment Block Grants: Sale or distribution of tobacco products to individuals under 18 years of age. Federal Register 1993;58:45156-74.

9 US Department of Health and Human Services, Substance Abuse and Mental Health Services Administration. Federal Register 1996;61:1492-509.

10 Philip Morris. Action Against Access advertisement. Roll Call 1995 Jun 29:12.

11 RJ Reynolds Tobacco Co. Actions speak louder than words. Advertisement. Boston Globe 1995 Jun 23:17.

12 RJ Reynolds Tobacco Company. Advertisement. Boston Globe 1992 Feb 7

13 Tobacco Institute. Tobacco: helping youth say no. Washington, DC: Tobacco Institute, 1987

14 Major new initiative to discourage youth smoking announced. (Tobacco Institute press release, $11 \mathrm{Dec}$ 1990, Washington, DC)

15 Ford YW. Letter from RJ Reynolds Tobacco Company to retailers, 2 May 1994.

16 DiFranza JR, Savageau JA, Aisquith BF. Youth access to tobacco: The effects of age, gender, vending machine locks and "It's the Law" programs. Am $\mathcal{f}$ Public Health 1996;86:221-4

17 DiFranza JR, Tye JB. Who profits from tobacco sales to children? $\mathscr{F} A M A$ 1990;263:2784-7.

18 Glantz SA, Barnes DE, Bero L, Hanauer P, Slade J. Looking through a keyhole at the tobacco industry. The Brown and Williamson Documents. FAMA 1995;274:219-24.

19 Tobacco Institute. Letter to Gale A Held, Center for Substance Abuse Prevention, 25 Oct 1993.

20 Kemper V. The inhalers. Common Cause Magazine 1995 Spring:18-23.
21 Bliley TJ. Letter to Gale A Held, Center for Substance Abuse Prevention, 25 Oct 1993.

22 Food Marketing Institute. Newsletter. 1994 Jan 31. Washington, DC: Food Marketing Institute.

23 State of Oklahoma, House of Representatives, Commerce, Industry and Labor Committee. Interim study 95-87, locd control of smoking regulations. 1995 Oct 9, State of Oklahoma : Oklahoma City, Oklahoma.

24 Neergaard L. Targeting teen smokers. Associated Press wire story, 1994 Mar 6.

25 Cecil JN. Vendors fail test of tobacco sale to minors Courier-fournal (Louisville, Kentucky) 1994 Jun 28:B2.

26 Blackham LM. Authorization of sting operations over sales $\varsubsetneqq$ alcohol and tobacco. Senate Bill No. 53, 1994 genera session, Utah.

27 Rose T. Store clerk acquitted in sale of cigarettes. Wilmin ton Star News (Wilmington, North Carolina) 1992 Aps 25:1A.

28 Kentucky Acts 1994, Chapter 480, page 1633.

29 South Dakota State Law 1994, Chapter 280, section 8 Regulation of tobacco products. Chapter 34-46, sections 34-46-1 to 34-46-6, Regulation of sales and distribution of tobacco products.

30 DiFranza JR, Norwood BD, Garner DW, Tye JB. Legislative efforts to protect children from tobacco. $¥ A M A 19879$ 257:3387-9.

31 Official Code of Georgia. Crimes and Offenses. Article tis 16-12-175.

32 Mississippi. House Bill No. 1268.

33 Tennessee. House Bill No. 2395, 1994 session.

34 Alabama, Prevention of Youth Access to Tobacco Act of 1994. Substitute for House Bill 137.

35 General Assembly of Pennsylvania, Senate Bill No. $177 \frac{f}{5}$ session of 1994

36 DiFranza JR. The AMA, tobacco, and the public health (letter). $\mathscr{f} A M A$ 1996; 275: 76-7.

37 Talbot B. "Adolescent smokers' rights laws". Tobacco Contr\$ू 1992;1:294-5.

38 Wagenaar AC, Wolfson $M$. Enforcement of the legdD minimum drinking age in the United States. $f$ Publt Health Policy 1994;15:37-53.

39 McConnell JLD. Indiana House Bill No. 1391, 199क session.

Sample from different states of legislative language suspected of having a commo tobacco industry source

\section{Alabama}

Any other use of persons under the age of 18 years to test compliance with this section or any other prohibition of like or similar import shall be unlawful and the person or persons responsible for such use shall be subject to the penalties prescribed in Section 4 of this act. ${ }^{34}$

\section{Georgia}

Any other use of persons under the age of 18 years to test compliance with this article or any other prohibition of like or similar import shall be unlawful and the person or persons responsible for such use shall be subject to the penalties prescribed in this article. ${ }^{31}$

\section{Indiana}

Any other use of an individual less than eighteen (18) years of age to test compliance with IC $35-467$ is unlawful and the person responsible for the testing is subject to the penalties under IC 35-46-713(c)..$^{3539}$

\section{Mississippi}

Any other use of persons under the age of eighteen (18) years to test compliance witt: Section 97-525 and this act or any other prohi bition of like or similar import shall be unlaw ful. ${ }^{32}$

\section{Pennsylvania}

Any other use of minors to test compliance with this act or any other prohibitions of like o. similar import shall be unlawful and the perso or persons responsible for such use shall, upotir conviction, be sentenced to pay a fine of... ${ }^{36}$

\section{South Dakota}

Any other use of persons under the age of eighteen to test compliance with this Act is unlawful and the persons responsible for such use are subject to the penalties prescribed io section 6 of this Act. ${ }^{29}$ 